notre recherche est de nature très scientifique et non pas nécessairement technique, les participants trouvent toujours un champs d'intérêt pour lequel ils voudraient en savoir plus, que ce soit au niveau de son application, de la recherche à venir ou de liens avec d'autres recherches ou d'autres partenaires. La possibilité de poser des questions en direct ne constitue pas seulement un avantage pour l'auditoire, mais également pour le conférencier puisqu'il est en mesure d'évaluer la réaction par rapport à ses recherches et à la direction suivie.

La diversité de l'auditoire du CIF/IFC représente également un élément important, puisqu'il n'est pas constitué uniquement des membres de l'Institut, même si les membres par euxmêmes représentent un excellent auditoire. L'Institut a la capacité de mettre en marché ses conférences électroniques pour rejoindre beaucoup plus de personnes que nous pourrions le faire, par l'entremise de ses contacts, ses listes de diffusion et la publicité par les réseaux sociaux. Le CCFB conserve habituellement le même thème pour sa série de conférences électroniques compte tenu du grand succès récolté. Nous aimons également organiser des conférences électroniques après la diffusion importante d'une publication. Deux exemples marquants de cet état de chose se retrouvent dans le cas du projet de la rivière Green dirigé par Doug Pitt et publié dans un numéro spécial du Forestry Chronicle en 2013. Un deuxième cas couvre la présentation de Joanne White intitulé « Les meilleures pratiques pour générer les caractéristiques d'inventaire forestier à partir des données numériques d'un relevé réalisé par laser aéroporté » effectuée en 2014. Joanne détient actuellement le record d'assistance alors que 675 personnes ont écouté sa présentation!
Le CCFB n'est pas la seule organisation à apprécier les conférences électroniques. Le succès général du programme est également reconnu par d'autres organismes et tandis qu'au cours des premières années le CIF/IFC devait aller à la recherche de conférenciers, la situation est maintenant telle que le nombre de demandes excède les places disponibles. L'Institut vise la diffusion de plus de 50 conférences électroniques en 2015, un niveau bien supérieur à la quarantaine de conférences par année.

Somme toue, nous souhaiterions reconnaître les succès des séries de conférences électroniques du CIF/IFC et souligner ce qu'ils ont fait pour que les gestionnaires forestiers, les intervenants en foresterie et les autres professionnels aient accès à nos recherches et nos innovations. Nous vous remercions pour ce magnifique programme.

\title{
PERSPEGTIUE
}

\section{The Next Chapter...}

am sure that most of you know we have recently hired a new Executive Director for the Canadian Institute of Forestry. After a nationwide search Dana Collins was the successful candidate in our thorough recruitment process. I want to thank Tat Smith for chairing this recruitment committee, the rest of the CIF/IFC Executive for their hard work, and most importantly, George Bruemmer and Keith Mc Clain for their sage advice and diligent efforts on our selection committee. Dana brings youthful enthusiasm, positive energy, and fresh ideas to the leadership of our Institute. I truly believe with Dana's leadership the CIF/IFC is well positioned for the future. I am well aware that selecting our next senior officer to lead the CIF/IFC is an incredibly important task; not only will this person guide us through the present, but more importantly this person will be key in defining what the we look like in the future. It is with the future in mind that I would like to focus this perspective on the next chapter of the CIF/IFC.
Organizations all over the world that rely on voluntary membership have been facing many challenges in the recent past. The CIF/IFC is no different. The old model of relying entirely on membership dues for revenue is no longer sustainable for voluntary organizations. We can thank John Pineau for positioning us well to face this reality, as the CIF/IFC currently relies on membership for about one third of our core revenue. I believe the next chapter of the Institute will see an increasing reliance on partnerships, sponsorships, and collaborations to grow our organization and continue to remain a relevant national organization. However, it will be very important that we do not compromise our brand in order to meet our growth objectives. We must continue to be seen as the honest brokers of forestry information in Canada. We must continue to advocate on behalf of sustainable forestry, with the key word being sustainable. Organizations that we partner with must clearly be like-minded. Our brand and our reputation are

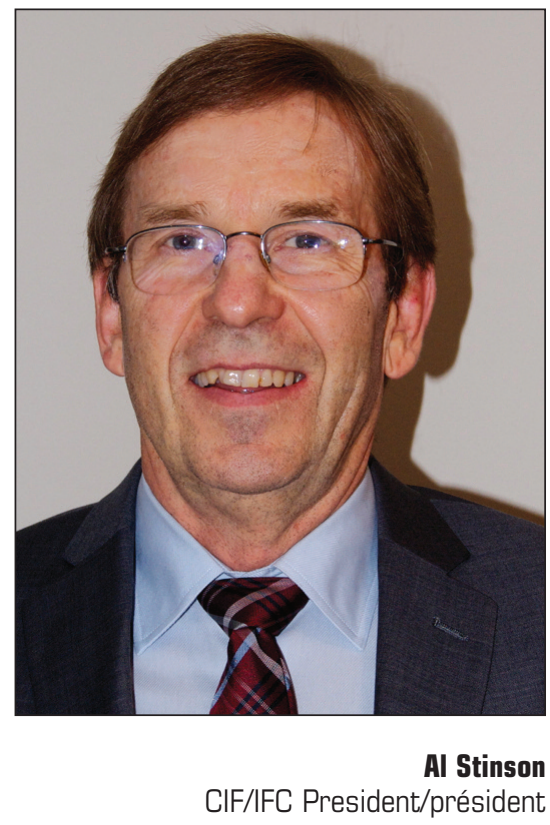

everything, and we must not comprise these in any way. In a national organization with thousands of members across Canada, not all members will always agree with the position we take. However, this is a symptom of Canada; we are a large country with many different regions, and many different opinions. 
At the end of the day we need to be able to connect our positions and our partnerships, with supporting sustainable forestry.

Even though membership has become an increasingly smaller portion of our annual revenue requirements, it is still a very important part of what we are. We need to grow our membership across Canada. I suspect the next chapter will focus on youth, and partnerships with existing professional forestry associations across Canada to accomplish our membership growth objectives. We need to capitalize on the captive audience we have through the Silver Ring program; we need to become more relevant to youth in the forestry profession; and, we need to communicate through platforms that will engage youth. Twitter and infographics will become an increasingly important piece of our communications strategies.

In my vision, the next chapter will see the CIF/IFC having a stronger national voice for forestry by aligning in some way more closely with the various professional associations. Imagine if we spoke with a voice representing 10000 practitioners across the country, our ability to influence policy, media communications, and awareness in general would be greatly increased. All of the various professional forestry associations across Canada have the common objective of ensuring our forests are well managed, and seen as such by the public. I am confident that we can somehow align more closely in the future and present a very strong collective voice for sustainable forestry in Canada.

Promoting competency amongst forest practitioners is core business for the CIF/IFC. We currently do this in many ways, through The Forestry Chronicle, on the ground workshops and conferences, and of course our e-lectures continue to grow in popularity with over 10000 attending each year. All of our current efforts fall into the area of continuing education; this is very important and we need to continue our efforts. However, I believe that we need to expand our competency focus to include provision of recognized academic training through blended learning opportunities. In order to grow in this area we will need to have strong partnerships with universities and colleges.

The world continues to shrink, as transportation and communication methods advance. We need to be seen as world citizens, important players in the forestry scene on a global scale. In order to do this, we need to partner with likeminded organizations around the world, and be strong advocates on behalf of sustainable forestry, promoting awareness around forestry issues based on fact.

We need someone leading our organization who is a strong communicator in innovative ways, someone who people want to work and partner with, someone who can engage youth, and someone with strong ethics who will not compromise our brand. Without strong leadership we will not accomplish the lofty goals that I have suggested might be part of the next chapter for the CIF/IFC. I believe that with Dana's youth, enthusiasm and passion we are well positioned to begin.

\section{Et l'histoire se poursuit...}

e suis certain que la plupart d'entre vous êtes au courant que nous avons embauché dernièrement une nouvelle directrice générale pour l'Institut forestier du Canada. Après un recrutement pancanadien, Dana Collins a été retenue à la suite de notre processus d'embauche. J'aimerais remercier Tat Smith pour avoir présidé le comité de sélection, l'ensemble des membres du bureau de direction du CIF/IFC pour leur implication soutenue et plus particulièrement George Bruemmer et Keith Mc Clain pour leurs précieux conseils et leurs implications au sein de notre comité de sélection. Dana nous arrive avec son enthousiasme débordant, son énergie positive et ses nouvelles idées pour la direction de notre Institut. Je considère sans hésitation que sous la direction de Dana, le CIF/IFC est en bonne posture pour les prochaines années. Je suis pleinement conscient que la sélection de la personne en charge de la direction du CIF/IFC constitue une démarche ardue car non seulement cette personne nous dirigera au cours des prochains mois, mais sur- tout parce que cette personne jouera un rôle déterminant pour définir ce que nous serons dans le futur. C'est en fonction de ce futur que je voudrais élaborer cet éditorial sur la suite de l'histoire du CIF/IFC.

Les organisations de toute la planète qui comptent sur l'implication de leurs membres ont fait face à plusieurs défis au cours des dernières années. Et le CIF/IFC n'échappe pas à cette situation. L'ancien modèle reposant entièrement sur les frais d'adhésion comme source de revenus n'est plus soutenable au sein des organisations composées de bénévoles. Nous souhaitons remercier John Pineau pour nous avoir obligés à faire face à cette réalité, de telle sorte que maintenant les membres de l'Institut comptent pour un tiers de l'ensemble de nos revenus. Je crois que la suite de l'histoire de l'Institut comportera un accroissement encore plus marqué des partenariats, des commandites et des collaborations pour soutenir la croissance de notre organisation et lui permettre de demeurer un organisme pertinent à l'échelle nationale. Cependant, il sera très important de ne pas compromettre notre image de marque pour atteindre nos objectifs de croissance. Nous devons maintenir notre image d'intermédiaires honnêtes de l'information forestière au Canada. Nous devons continuer de plaider pour une foresterie durable, le mot clé étant « durable ». Les organisations avec lesquelles nous avons établies un partenariat doivent être clairement animées par les mêmes motifs. Notre image et notre réputation sont l'essence de ce que nous sommes, et nous devons faire en sorte de ne pas les compromettre en aucune façon. Au sein d'une organisation nationale comptant des milliers de membres de partout au Canada, il se peut que tous les membres ne soient pas toujours d'accord avec les positions que nous soutenons. Cependant, ceci est le reflet de ce qu'est le Canada : un vaste pays comprenant plusieurs régions différentes et une multitude d'opinions. Somme toute, il nous faut être en mesure d'afficher nos positions et nos partenariats, tout en appuyant la foresterie durable. 
Même si les frais d'adhésion comptent pour une portion de plus en plus petite de nos revenus annuels, les membres demeurent un élément important de ce qui constitue l'Institut. Il nous faut accroître le nombre de membres partout au Canada. J'estime que pour la suite de l'histoire, il nous faut nous concentrer sur les jeunes diplômés et sur les partenariats avec les associations professionnelles de forestiers en place partout au Canada si nous voulons atteindre nos objectifs de croissance en termes de membres. Il nous faut tirer profit de l'auditoire captif constitué par le programme de remise des joncs d'argent; il nous faut faire en sorte d'être encore plus pertinent pour les récents diplômés en foresterie et nous devons apprendre à communiquer au moyen de plateformes attrayantes pour les jeunes. Twitter et l'infographie prendront de plus en plus d'importance au sein de notre stratégie de communication.

Selon moi, la suite de l'histoire du CIF/IFC verra l'Institut devenir un porte-parole plus important de la foresterie alors qu'il se rapprochera en quelque sorte des différentes associations professionnelles. Imaginez que nous représentions quelque 10000 forestiers de partout au Canada, notre capacité à influencer l'élaboration des politiques, à communiquer avec les médias et à accroître la sensibilisation envers la foresterie s'en trouverait accrue de façon formidable. Toutes les associations professionnelles de forestiers du Canada ont en commun d'assurer que nos forêts soient correctement aménagées et que cela soit perçu comme tel par le public. Je suis certain que nous pouvons d'une façon ou d'une autre nous aligner sur cet objectif dans un proche avenir et devenir un porte-parole reconnu de tous de la foresterie durable au Canada.

Promouvoir la compétence parmi les professionnels de la foresterie constitue un point crucial de l'engagement du CIF/IFC. Nous y veillons actuellement par la publication du Forestry Chronicle, par des ateliers techniques sur le terrain et des conférences, ainsi que bien sûr par les conférences électroniques qui continuent de gagner en popularité avec plus de 10000 participants chaque année. Toutes ces initiatives sont regroupées sous le domaine de la formation continue; nous sommes conscients de son importance et il nous faut poursuivre nos efforts. Toutefois, je considère qu'il nous faut accentuer notre attention sur la compétence en y incluant des dispositions liées à une formation académique reconnue à partir d'un ensemble d'opportunités d'apprentissage. De façon à développer ce domaine, il nous faudra établir de solides partenariats avec les universités et les collèges.

Le monde devient de plus en plus petit à mesure que les modes de transport et de communication progressent. Nous devons être perçus comme des citoyens du monde, des joueurs de premier plan de la scène forestière à l'échelle de la planète. Pour y parvenir, nous devons établir des partenariats avec les organisations qui partagent notre vision partout dans le monde et plaider fermement pour la foresterie durable et faire progresser l'intérêt sur les enjeux forestiers à partir de données concrètes.

Il nous faut une personne à la tête de notre organisation qui soit un communicateur chevronné prêt à utiliser de nouveaux outils, une personne avec laquelle les gens veulent travailler et collaborer, une personne qui peut rassembler les jeunes et dont l'éthique ne mettra pas en péril notre image. En l'absence d'un leadership déterminant, nous ne serons pas en mesure d'atteindre les nobles objectifs que j'ai mentionnés pour la suite de l'histoire du CIF/IFC. J'estime que l'enthousiasme et la passion de la jeunesse chez Dana nous permettra de bien entreprendre la suite de notre histoire.

\section{OF RELEUANGE \& QUEGTION DUIFFORMATION}

\section{Ensyn-A Biofuels Success Story}

small plant in Renfrew, Ontario is transforming sawdust into a highvalue forest product-a heating oil replacement. While "green" energy has become increasingly popular in the last several years, Ensyn has been in the green energy business for over two decades. Ensyn's technology has quietly made over 40 million gallons of bio-oil since 1989. Long a commercial success, Ensyn has ramped up production of its renewable fuel oil (RFO) in the Renfrew plant to meet increasing customer demand. The plant is now producing
RFO 24/7, employing 40 people and providing spin-off jobs to local sawmills, trucking contractors and tradespeople.

Ensyn's patented technology, Rapid Thermal Processing (RTP ${ }^{\mathrm{TM}}$ ) is the brainchild of Ottawa natives Dr. Robert Graham and Barry Freel, who developed the process while pursuing undergraduate studies at the University of Western Ontario. RTP ${ }^{\mathrm{TM}}$ converts solid biomass to high yields of a liquid product-or "liquid wood"-in less than two seconds. This liquid wood can be used as a replacement for heating fuel and as a renewable feedstock for refineries for the production of gasoline and diesel.

Ensyn's product has become more marketable for several reasons. Ian Barnett, Executive Vice President of Ensyn, says "Greater environmental concern about burning fossil fuels and their contribution to climate change as well as global turmoil raising concerns about energy security have worked in our favour. Today, there are both formal and informal supports for renew- 